\title{
Tumour Response After Palliative Radiotherapy: Influence on Head and Neck Cancer Patients Survival
}

\section{Resposta Tumoral Após Radioterapia Paliativa: Influência na Sobrevivência dos Doentes de Cabeça e Pescoço}

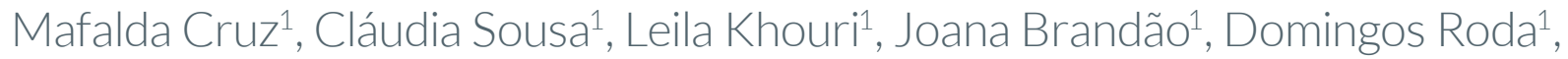
Gilberto Melo ${ }^{1}$, Paula Alves ${ }^{1}$

\section{ABSTRACT}

INTRODUCTION: Palliative radiotherapy provides improved quality of life in head and neck cancer patients. Little is known regarding the influence of palliative radiotherapy on locoregional control and survival rates.

Our objective was to evaluate tumour response after palliative radiotherapy for head and neck cancer patients and its influence on overall survival.

MATERIAL AND METHODS: Retrospective study of patients diagnosed with head and neck cancer who completed palliative radiotherapy to primary local-regional sites between January 2014 and December 2016. Tumour response patterns were evaluated following a cervical and chest computed tomography performed 4-6 weeks after the end of the treatment. Differences between groups were compared using ANOVA and Chi-square test.

RESULTS: We included 53 patients in our study. Radiotherapy schemes were $50 \mathrm{~Gy} / 20 \mathrm{fr}$ in $35.8 \%$ of our patients, $30 \mathrm{~Gy} / 10 \mathrm{fr}$ (32.1\%), $37.5 \mathrm{~Gy} / 15 \mathrm{fr}$ (18.9\%) and $40 \mathrm{~Gy} / 20 \mathrm{fr}$ (13.2\%). A percentage of $61.2 \%$ of the patients had a partial response on computed tomography and 10.2\% had complete response. After a mean follow-up period of 27.2 months, mean overall survival was 9.55 months ( \pm 9.3 ). There were no differences in overall survival between the four radiotherapy schemes $(p=0.41)$. Patients who had better tumour response on computed tomography had a propensity for longer overall survival $(p=0.011)$.

CONCLUSION: There is no consensus regarding the choice of the optimal radiotherapy fractionation scheme used in palliative care of head and neck cancer patients. Patients with advanced incurable head and neck cancer have a poor prognosis but the addition of palliative radiotherapy provides better local-regional control of the disease with the possibility of longer survival rates.

KEYWORDS: Head and Neck Neoplasms/radiotherapy; Palliative Care; Radiotherapy; Radiotherapy, Intensity-Modulated 


\section{RESUMO}

INTRODUÇÃO: A radioterapia com intuito paliativo tem um conhecido impacto na qualidade de vida dos doentes com tumores de cabeça e pescoço. São escassos os estudos que avaliam o impacto de esquemas paliativos de radioterapia relativamente ao controlo locorregional e sobrevivência global.

O objectivo do estudo foi avaliar a resposta imagiológica tumoral e a sua influência na sobrevivência global em doentes com cancro de cabeça e pescoço submetidos a radioterapia paliativa.

MATERIAL E MÉTODOS: Estudo retrospetivo que inclui doentes com diagnóstico de cancro de cabeça e pescoço submetidos a radioterapia paliativa entre janeiro de 2014 e dezembro de 2016. Padrões de resposta tumoral avaliados em tomografia computorizada cervico-torácica 4-6 semanas após o final do tratamento. Análise de diferenças entre grupos através dos testes ANOVA e Chi-square.

RESULTADOS: Foram incluidos 53 doentes no estudo. Os esquemas de RT realizados foram: 50 Gy/20 fr (em 35,8\% dos doentes), 30 Gy/10 fr (32,1\%), 37,5 Gy/15 fr (18,9\%) e 40 Gy/20 fr (13,2\%). Na tomografia computorizada de avaliação de resposta ao tratamento, 61,2\% dos doentes obtiveram resposta parcial e 10,2\% resposta completa. Após um período de follow-up médio de 27,2 meses, a sobrevivência média foi de 9,55 meses ( \pm 9,3). Quando analisados os esquemas de radioterapia separadamente, não houve diferenças estatisticamente significativas relativamente à sobrevivência média ( $p=0,41)$. A sobrevivência média dos doentes que obtiveram uma boa resposta imagiológica é tendencialmente superior à dos doentes com má resposta $(p=0,011)$.

CONCLUSÃO: Não existe atualmente consenso relativamente à escolha do fracionamento com intuito paliativo utilizado em neoplasias de cabeça e pescoço. A realização de radioterapia paliativa pode providenciar um maior controlo locorregional da doença com a possibilidade de maiores taxas de sobrevivência.

PALAVRAS-CHAVE: Cuidados Paliativos; Neoplasias de Cabeça e Pescoço/radioterapia; Radioterapia; Radioterapia de Intensidade Modulada

\section{INTRODUCTION}

Head and neck (H\&N) cancer accounts for more than 500000 cases annually and represents the third most common cause of cancer death in worldwide. More than 90\% are squamous cell carcinomas, and the disease typically appears in the oropharynx, oral cavity, hypopharynx, or larynx. Males are affected significantly more than females with a ratio ranging from 2:1 to 4:1.1

The development of H\&N squamous cell carcinoma is the result of the interaction of both environmental factors and genetic inheritance, and is therefore, multifactorial. The risk factors most frequently associated with head and neck cancer include smoking, alcohol consumption, human papillomavirus infection (especially for oropharyngeal cancers), and Epstein-Barr virus infection (for nasopharyngeal cancers). ${ }^{2}$ These tumours affect basic physiologic functions (i.e., the ability to chew, swallow, and breathe), the senses (taste, smell, hearing), and uniquely human characteristics (i.e., appearance, voice). ${ }^{3}$ Because the entire aerodigestive tract epithelium may be exposed to these carcinogens, patients with $H \& N$ cancers are at risk for developing second primary neoplasms of the H\&N, lung, esophagus and others sites that share these risk factors. A proportion of patients with head-and-neck cancer are not candidates for cura- tive therapy because of advanced stage, poor performance status, medical comorbidities or a combination of these factors. The five-year survival, even with aggressive treatment, is less than $20 \%$, with a median survival of around 12 months. ${ }^{4-6}$ Even in this setting, local-regional control remains paramount given the importance of the head and neck to self-image and to the basic human functions. It is widely recognized that radiotherapy (RT) provides effective palliation and improved quality-of-life in advanced incurable malignancies, accounting for a significant portion of cancer care across the world. For patients with metastatic disease who have gross tumour at local-regional sites, therapeutic decision-making is complicated by the need to balance the prospects of disease control and quality of life. Although evidence from previous studies have suggested that palliative RT is associated with improved outcomes in these patients, consensus guidelines or level I evidence are lacking to direct the optimal choice of palliative RT regimens. Poor compliance to therapy, limited enrolment in prospective trials and high attrition rates render outcome assessment difficult and challenging in this population. Decisions regarding RT, including dose, fractionation, target volumes and technique are made at the discretion of the radiation oncologist and are often influenced by patient-related factors, including age, performance status (PS), 
treatment goals and anatomic regions involved. Additionally, little has been written regarding tumour response and local-regional control after palliative RT in H\&N cancer.

This study aims to determine tumour response in head and neck cancer patients who underwent different fractionation schemes of palliative RT. Additionally, we aim to evaluate the influence of different RT schemes and tumour response on overall survival.

\section{MATERIAL AND METHODS}

This is a retrospective unicentre study of patients diagnosed with H\&N cancer not suitable for curative treatment either by advanced disease, poor PS, or a combination of both. Those patients completed palliative radiotherapy to primary local-regional sites at our department between January 2014 and December 2016. Decisions regarding radiation therapy, including fractionation and target volumes were typically individualized depending on the particular details of each case and made at the discretion of the radiation oncologist. Radiation therapy was delivered using a mega-voltage linear accelerator with 6-15 MV photons. Treatment technique was either 3D conformal radiation therapy or intensity modulated radiation therapy, depending on disease prognostic and patient's PS. Target volumes generally included the gross tumour volume with a $0.5-1 \mathrm{~cm}$ margin. Tumour response patterns were evaluated following a cervical and chest computed tomography (CT) 4-6 weeks after RT as well as clinical evaluation by an otorhinolaryngologist. Patterns of imagiologic response followed the RECIST criteria ${ }^{7}$ for solid tumours in which a complete response (CR) correlates to the disappearance of all target lesions and partial response (PR) to $a \geq 30 \%$ decrease in the sum of target lesions. Stable disease (SD) correlates to neither response nor progression and progressive disease (PD) to a $\geq 20 \%$ increase in the sum of target lesions. Data were analysed on an intention to treat basis using SPSS (Statistical Package for Social Sciences, Chicago, Illinois, USA version 23). Differences between groups were compared using ANOVA and Chi-square test.

\section{RESULTS}

A total of 53 patients were included in this study and $73.4 \%$ were male. Mean age was 71.3 years $( \pm 12.2$ ). Primary tumour was localized in oropharynx in 34.0\% of the patients, followed by oral cavity (20.8\%) and larynx (18.9\%). A vast majority of $92.4 \%$ of the tumours were histologically classified as squamous cells carcinoma
(SCC). At the time of the diagnosis, $86.8 \%$ of the patients had stage IV disease.

RT palliative schemes were 50 Gy delivered in 20 fractions during 4 weeks (50 Gy/20 fr/4 w) in 35.8\% of our patients, $30 \mathrm{~Gy} / 10 \mathrm{fr} / 2 \mathrm{w}$ in 32.1\%, $37.5 \mathrm{~Gy} / 15 \mathrm{fr} / 3 \mathrm{w}$ in $18.9 \%$ and $40 \mathrm{~Gy} / 20 \mathrm{fr} / 4 \mathrm{w}$ in $13.2 \%$ of our patients (Table 1).

After the analysis of cervical and chest CT, $61.2 \%$ of the patients had partial response, imagiologic progression

TABLE 1. Characteristics of the study population.

\begin{tabular}{|c|c|c|c|c|}
\hline & $\mathbf{N}$ & $\%$ & Mean & SD \\
\hline PATIENTS & 53 & & & \\
\hline Age (years) & & & 71.3 & \pm 12.2 \\
\hline \multicolumn{5}{|l|}{ Gender } \\
\hline Male & 39 & 73.9 & & \\
\hline Female & 14 & 26.1 & & \\
\hline Karnofsky PS & & & 68.7 & \\
\hline$\leq 60 \%$ & 21 & 39.6 & & \\
\hline$>60 \%$ & 32 & 60.4 & & \\
\hline \multicolumn{5}{|l|}{ Histology } \\
\hline SCC & 49 & 92.5 & & \\
\hline Other & 4 & 7.5 & & \\
\hline \multicolumn{5}{|l|}{ Stage } \\
\hline IV & 46 & 86.8 & & \\
\hline III & 5 & 9.4 & & \\
\hline I and I| & 2 & 3.8 & & \\
\hline \multicolumn{5}{|l|}{ Tumor site } \\
\hline Oropharynx & 18 & 34.0 & & \\
\hline Oral cavity & 11 & 20.8 & & \\
\hline Larynx & 10 & 18.9 & & \\
\hline Hypopharynx & 5 & 9.4 & & \\
\hline Other & 9 & 16.9 & & \\
\hline \multicolumn{5}{|l|}{ RT scheme } \\
\hline $50 \mathrm{~Gy} / 2 \mathrm{Ofr}$ & 19 & 35.8 & & \\
\hline 30Gy/10fr & 17 & 32.1 & & \\
\hline $37,5 \mathrm{~Gy} / 15 \mathrm{fr}$ & 10 & 18.9 & & \\
\hline $40 \mathrm{~Gy} / 20 \mathrm{fr}$ & 7 & 13.2 & & \\
\hline
\end{tabular}

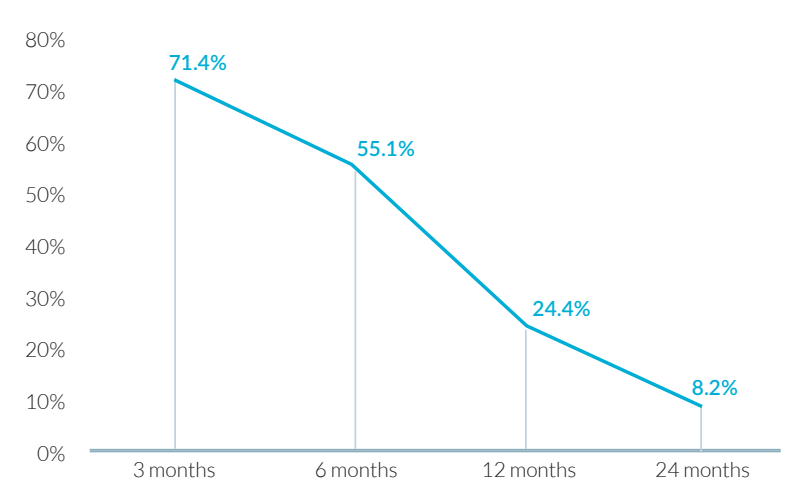

FIGURE 1. Overall survival. 
TABLE 2. RT scheme, tumour response and mean overall survival.

\begin{tabular}{|c|c|c|c|c|c|}
\hline Fractionation & $\begin{array}{c}\text { Finished planned } \\
\text { RT (n) }\end{array}$ & $\begin{array}{l}\text { Motive for } \\
\text { interruption }\end{array}$ & $\begin{array}{c}\text { Imagiologic response } \\
n(\%)\end{array}$ & $\begin{array}{c}\text { Mean overall } \\
\text { survival (months) }\end{array}$ & ANOVA \\
\hline $50 G y / 20 f x$ & $19 / 19$ & - & 17/19-(89.4\%) & 10 & \multirow{4}{*}{$p=0.41$} \\
\hline 30Gy/10fx & $15 / 17$ & Death Fistula & 9/15-(60\%) & 11.8 & \\
\hline $37,5 \mathrm{~Gy} / 15 \mathrm{fx}$ & $9 / 10$ & Death & 5/9-(55.5\%) & 5.2 & \\
\hline $40 G y / 20 f x$ & $6 / 7$ & Grade-3-toxicity & 4/6-(66.7\%) & 8.2 & \\
\hline
\end{tabular}

TABLE 3. Influence of tumour response on overall survival.

\begin{tabular}{|c|c|c|c|}
\hline Tumor response & $\begin{array}{c}\text { Number } \\
\text { of patients } \\
(n)\end{array}$ & $\begin{array}{c}\text { Mean overall } \\
\text { survival } \\
\text { (months) }\end{array}$ & $\begin{array}{c}\text { Chi square } \\
\text { test }\end{array}$ \\
\hline $\begin{array}{c}\text { Complete } \\
\text { response }\end{array}$ & 5 & 11.2 & \\
\hline $\begin{array}{c}\text { Partial response } \\
\text { Total (good } \\
\text { response) }\end{array}$ & 30 & 12 & \\
\hline $\begin{array}{c}\text { Stable disease } \\
\text { Progression }\end{array}$ & 10 & 11.6 & 0.011 \\
\hline $\begin{array}{c}\text { Total (bad } \\
\text { response) }\end{array}$ & 14 & 10.6 & \\
\hline
\end{tabular}

was seen in $18.4 \%, 10.2 \%$ showed complete response and $8.2 \%$ had stable disease.

After a mean follow-up period of 27.2 months ( \pm 8.3), mean overall survival was 9.55 months ( \pm 9.3$)$. The overall survival 3 months after treatment was $71.4 \%, 24.4 \%$ after 1 year and 8.2\% after 2 years (Fig. 1).

The group with better tumour response on CT was the group that underwent the $50 \mathrm{~Gy} / 20 \mathrm{fr} / 4 \mathrm{w}$ scheme (in which $89.4 \%$ had partial/complete response) with no need for interruption of the treatment due to toxicity. Two patients died during the $30 \mathrm{~Gy} / 10 \mathrm{fr} / 2 \mathrm{w}$ and the $37.5 \mathrm{~Gy} / 15 \mathrm{fr} / 3$ w scheme due to disease progression and two other patients had the need for interruption of treatment due to a tracheoesophageal fistula and a RTOG grade 3 oral mucositis.

RT schemes and tumour response were not compared statistically.

The groups with longer overall survival rates were the groups that underwent the $30 \mathrm{~Gy} / 10 \mathrm{fr} / 2 \mathrm{w}$ (11.8 months) and the $50 \mathrm{~Gy} / 20 \mathrm{fr} / 4 \mathrm{w}$ (10 months) schemes. The group treated with the $40 \mathrm{~Gy} / 20 \mathrm{fr} / 4 \mathrm{w}$ scheme had a mean overall survival of 8.2 months. On the opposite site, the shortest mean overall survival was verified after the $37.5 \mathrm{~Gy} / 15 \mathrm{fr} / 3 \mathrm{w}$ scheme (5.2 months). Despite these results, there were no statistically significant differences between the four RT schemes and mean overall survival ( $p=0.41$ ) (Table 2 ).

In order to compare imagiologic response, we divided our patients in two groups based on their good or bad response on CT. In order to do so, patients with complete or partial response were classified as "good response" and patients with stable disease or progression were classified as "bad response". In our study, patients who had a good response on CT ( $n=35)$ had longer overall survival comparing to patients who had a bad response $(n=14)$ (11.6 months vs 6.65 months; $p=0.011$ ) (Table 3).

\section{DISCUSSION FRACTIONATION}

There is no consensus regarding the choice of the optimal RT fractionation scheme used in palliative care of H\&N cancer patients. ${ }^{3}$ To date, there are no large prospective randomized controlled trials of palliative RT in advanced incurable H\&N cancer. It has been argued that a higher total dose is needed for growth restraint and sustained palliation in this cases. Various dose-fractionation schedules that have been used for palliation in other tumour sites have been extrapolated for use in palliative head-neck radiotherapy, and the schemes mentioned previously were chosen based on that assumption.

Patients with poor performance status or significant comorbid disease can benefit from the so-called "quad shot" regimen of 14 Gy in four fractions over 2 consecutive days with the opportunity to repeat this same dosing twice at 4-week intervals, for a potential total dose of $42 \mathrm{~Gy} .8$. We did not include any patient in this regimen due to the inconvenience of integrating a twice-daily fractionation schedule in our clinical practice.

The results of our analysis demonstrate an apparent equivalence of various fractionation schemes in providing palliation at the primary local-regional sites.

\section{TUMOUR RESPONSE}

Locoregional tumour progression is the predominant cause of death in patients with head-and-neck cancer. ${ }^{10}$ Therefore, achieving local control in patients with advanced or recurrent disease may impact survival. ${ }^{11}$ The observation that nearly three fourths of the patients in our study had a good tumour response strongly suggests that palliative radiation therapy should continue to be 
recommended in this setting. Although the main purpose of this palliative treatment is to provide symptomatic relief and local-regional control of the disease, we emphasize the high number of partial and complete responses observed in our study.

A retrospective analysis of a single-institution experience found improved overall survival when local tumour control was achieved in patients undergoing reirradiation for recurrent head-and-neck cancer. ${ }^{12}$ The present study demonstrates that a good tumour response on CT tends to correlate with better overall survival rates. As expected, we found that higher dose regimens, such as the $50 \mathrm{~Gy} / 20 \mathrm{fr} / 4 \mathrm{w}$ scheme, maximize tumour response on CT evaluation.

Being a retrospective study, quality of life improvement and treatment toxicities could not be ascertained.

\section{SURVIVAL RATES}

There is no level 1 evidence regarding the use of palliative head and neck radiotherapy. In a retrospective study, ${ }^{13}$ forty patients with advanced neck disease from an unknown primary were treated with either $30 \mathrm{~Gy} / 10$ $\mathrm{fr} / 2$ weeks or $20 \mathrm{~Gy} / 2 \mathrm{fr}$ with a 1-week inter-fraction interval. There was a good 1 -year response rate $(77 \%$ and $48 \%$ respectively), with a similar symptomatic response rate of $68 \%$ and $38 \%$, respectively.

Best supportive care alone is associated with a median survival of three to six months in H\&N advanced squamous cell carcinoma. ${ }^{14,15}$ In the largest study on the natural history of untreated head and neck cancer, ${ }^{14} 808$ patients were followed-up until their death and all patients were given best supportive care. The median overall survival was 100 days (range 1 day to 53.8 months). Approximately 50\% of untreated patients died within 4 months of diagnosis, but a small subset of patients with low tumour burden and good performance status survived up to 4 years. Our study showed a mean overall survival of 9.55 months, which is higher than best supportive care studies and, therefore, consistent with the existing literature.

Minatel et a ${ }^{16}$ used a high dose regimen for palliation in inoperable H\&N cancer patients. They treated 58 patients with split-course radiotherapy, consisting of 50 Gy/20 fractions with a 2-week break after the first 25 Gy with concurrent bleomycin. This regimen was associated with a local control rate of $69 \%$ with median response of seven months.

In our study we observed that the fractionation scheme does not influence overall survival in a statistical significant way.
In view of the relatively short median survival observed in this analysis, the importance of the adequate treatment duration cannot be overstated among patients with advanced $\mathrm{H} \& \mathrm{~N}$ cancer.

In fact, the group with higher survival rates was the group that underwent for a 10 fraction scheme instead of longer treatment schemes. This raises the question whether the inconvenience (often with the need of hospitalization) of an extended course of radiation therapy outweighs the modest benefits in those with an already limited life expectancy. Having this in mind, the importance of careful patient selection must be recognized when palliative radiotherapy is used.

In our study, the group with better tumour response (50 $\mathrm{Gy} / 20 \mathrm{fr}$ ) was not the group with longer survival rates (30 Gy/10 fr). We believe this may be related with the short number of patients included in the study. However, after a division in two groups based on tumour response (and the group "good response" includes patients from both the $50 \mathrm{~Gy} / 20 \mathrm{fr}$ and $30 \mathrm{~Gy} / 10 \mathrm{fr}$ schemes), we can demonstrate that good responders have a tendency for better survival rates.

\section{CONCLUSION}

The present study, along with other published series, has demonstrated that despite the short median overall survival in this population, the addition of palliative RT may delay tumour progression and is well tolerated. Our findings that a good tumour response tends to correlate with improved overall survival suggest that palliative regimens should be given to carefully selected patients with advanced H\&N cancer. More studies should be carried out in order to evaluate other predictive factors of tumour response as a mean for improving patient's quality of life and survival rates.

CONFLICTS OF INTEREST: The authors declare that they have no conflicts of interest.

FINANCIAL SUPPORT: This work has not received any contribution, grant or scholarship.

CONFIDENTIALITY OF DATA: The authors declare that they have followed the protocols of their work center on the publication of data from patients.

PROTECTION OF HUMAN AND ANIMAL SUBJECTS: The authors declare that the procedures followed were in accordance with the regulations of the relevant clinical research ethics committee and with those of the Code of Ethics of the World Medical Association (Declaration of Helsinki). 
CONFLITOS DE INTERESSE: Os autores declaram não ter qualquer conflito de interesse na realização do presente trabalho.

FONTES DE FINANCIAMENTO: Não houve qualquer fonte de financiamento na realização do presente trabalho.

CONFIDENCIALIDADE DOS DADOS: Os autores declaram ter seguido os protocolos da sua instituição acerca da publicação dos dados de doentes.

PROTEÇÃO DE PESSOAS E ANIMAIS: Os autores declaram que os procedimentos seguidos na elaboração do presente trabalho estão em conformidade com as normas das comissões de investigação clínica e de ética, bem como da declaração de Helsínquia e da Associação Médica Mundial.

\section{REFERENCES}

1. Fanucchi M, Khuri Fadlo R, Shin D, et al. Update in the management of head and neck cancer. Update Cancer Therap. 2016;1:211-21

2. Halperin E, Perez C. Perez \& Brady's Principles and Practice of Radiation Oncology. $6^{\text {th }}$ ed. Philadelphia: Wolters Kluwer; 2013.

3. Chen A, Vaughan A, Narayan S, Vijayakumar S. Palliative radiation therapy for head and neck cancer: toward an optimal fractionation scheme. Head Neck. 2008;30:1586-91. doi: 10.1002/hed.20894.

4. Carvalho AL, Salvajoli JV, Kowalski LP. A comparison of radio therapy or chemotherapy with a symptomatic treatment alone in advanced head and neck carcinomas. Eur Arch Otorhinolaryngol. 2000;257:164-7.

5. Grau C, Agarwal JP, Jabeen K, Jabeen K, Rab Khan A, Abeyakoon S, et al. Radiotherapy with or without mitomycin $\mathrm{c}$ in the treatment of locally advanced head and neck cancer: results of the IAEA multicentre randomized trial. Radiother Oncol. 2003;67:17-26.

6. Vikram B. Cancers of the head and neck in developing countries. Radiother Oncol. 2003;67:1-2.

7. Fournier L, Ammari S, Thiam R, Cuénod CA. Imaging criteria for assessing tumor response: RECIST, mRECIST, Cheson. Diagn Interv Imaging. 2014;95:689-703. doi: 10.1016/j. diii.2014.05.002.

8. Corry J, Peters LJ, Costa ID, Milner AD, Fawns H, Rischin D, et al. The 'QUAD SHOT': A phase II study of palliative radiotherapy for incurable head and neck cancer. Radiother Oncol. 2005;77:137-42.

9. Lok BH, Jiang G, Gutiontov SI, Lanning RM, Sridhara S, Sherman EJ, et al. Palliative radiation therapy by the RTOG 85-02 regimen for incurable primary or metastatic head and neck cancers. Oral Oncol. 2015;51:957-62. doi: 10.1016/j.oraloncology.2015.07.011.

10. Coatesworth AP, Tsikoudas A, MacLennan K. The cause of death in patients with head and neck squamous cell carcinoma. J Laryngol Otol. 2002;116:269-71.

11. McDonald MW, Lawson J, Garg MK, Quon H, Ridge JA, Saba $\mathrm{N}$, et al. ACR appropriateness criteria retreatment of recurrent head and neck cancer after prior definitive radiation expert panel on radiation oncology: Head and neck cancer. Int J
Radiat Oncol Biol Phys. 2011;80:1292-8. doi: 10.1016/j.ijrobp.2011.02.014.

12. Lee N, Chan K, Bekelman JE, Zhung J, Mechalakos J, Narayana A, et al. Salvage re-irradiation for recurrent head and neck cancer. Int J Radiat Oncol Biol Phys. 2007;68:731-40.

13. Erkal HS, Mendenhall WM, Amdur RJ, Villaret DB, Stringer SP. Squamous cell carcinomas metastatic to cervical lymph nodes from an unknown head and neck mucosal site treated with radiation therapy with palliative intent. Radiother Oncol. 2001;59:319-21.

14. Stell PM. Survival times in end-stage head and neck cancer. Eur J Surg Oncol. 1989;15:407-10.

15. Kowalski LP, Carvahlo AL. Natural history of untreated head and neck cancer. Eur J Cancer. 2000;36:1032-7.

16. Minatel E, Gigante M, Franchin G, Gobitti C, Mascarin M, Bujor $L$, et al. Combined radiotherapy and bleomycin in patients with inoperable head and neck cancer with unfavourable prognostic factors and severe symptoms. Oral Oncol. 1998;34:11922. 